\title{
The effect of a low-protein diet, and of refeeding, on the composition of liver and muscle in the weanling rat
}

\author{
By C. B. MENDES* AND J. C. WATERLOW \\ Medical Research Council, Tropical Metabolism Research Unit, \\ University College of the West Indies, Famaica, B.W.I.
}

(Received $30 \mathcal{F u l y}$ 1957)

In any study of the effect of malnutrition on the composition of tissues the first problem to be faced is the standard of reference. In the adult organism the deoxyribonucleic acid (DNA) of the nucleus seems to be the least variable of all tissue constituents. The amount of DNA in a cell is related to its genetic make-up, and in a given species seems to be constant for all diploid cells (Boivin, Vendrely \& Vendrely, I948; Pollister, Swift \& Alfert, I95I). It is to be expected, therefore, that the DNA content of a cell or an organ will not be affected by environmental influences except in so far as they stimulate or repress cell division.

Most studies of the effect of diet on DNA content have been done on the liver. This organ is atypical, because in the adult a large proportion of its cells is polyploid (Harrison, I95 I, r953). In the rat at birth the average liver cell is diploid; during growth the degree of polyploidy steadily increases (Jacob, Mandel \& Mandel, I954; Fukuda \& Sibatani, r953). Microscopists indeed have long recognized that during growth there is an increase in the average size of the liver-cell nucleus (Boehm, 1932). The total liver DNA increases in the growing animal pari passu with the body-weight (Campbell \& Kosterlitz, I949-50; Jacob et al. 1954). The data of Jacob et al. show that in rats between the ages of 8 and 60 days the total liver DNA increased twelve times. The mean DNA per nucleus rose by a factor of $I \cdot 3$, so that there must have been a ninefold increase in the number of cells. In the adult rat it has been clearly established that the total DNA of the liver and the average amount of DNA per nucleus are not altered either by starvation or by diets deficient in protein or essential amino-acids (Mandel, Jacob \& Mandel, 1950; Campbell \& Kosterlitz, 1952; Thomson, Heagy, Hutchison \& Davidson, I953). Less information is available about the effect of malnutrition in the young animal on the two processes that contribute to the normal growth of liver DNA-multiplication of cells and increase in DNA content per cell. Fukuda \& Sibatani (1953) maintained rats on a calorie-deficient diet, so that at an age when they should have weighed $15 \circ \mathrm{g}$ they weighed only $5 \circ \mathrm{g}$. The DNA per liver cell nucleus was the same as in normal rats of the same body-weight, and less than in normal rats of the same age. In other words, the dietary restriction arrested the normal increase in liver-cell DNA, and held it at the level appropriate to the body-weight. On the other hand, Ely \& Ross (195I) found an increased DNA content per nucleus, compared with controls, in young rats kept for periods up to 7 weeks on a diet poor in

* Biochemist, Government of Jamaica, Nutrition Research Unit. 
protein. In neither of these papers are values given from which it is possible to deduce the effect of the diet on total liver DNA.

Observations of this kind have a bearing on the theoretical question of the relation between DNA formation and the processes of growth and cell division. They are also important in relation to practical problems encountered in human nutrition. It is from that point of view that the experiments described in this paper were undertaken. In a previous study (Waterlow \& Weisz, 1956) on liver-biopsy specimens from malnourished human infants, it was shown that the ratio of protein N to DNA-phosphorus (DNAP) increased from about $50 \mathrm{mg} / \mathrm{mg}$ soon after admission to hospital to about $80 \mathrm{mg} / \mathrm{mg}$ at the end of treatment. From these figures, however, it was not possible to deduce the increase in total liver protein produced by treatment-or, to put it in another way, the deficit in total liver protein produced by malnutrition-since it had to be assumed that the other factor in the ratio-the DNA content-also changed during recovery. The experimental work cited above gives no information about the changes in total liver DNA that occur during refeeding after a period of dietary deficiency.

These measurements of the ratio N:DNAP made on human liver were designed to give information about the degree of protein depletion of the patient. However, it was shown by Addis, Poo \& Lew (1936) that in an animal kept for any length of time on a protein-deficient diet the muscles lose relatively as well as absolutely more protein than any other organ. This finding was confirmed in the human subject by preliminary analyses of tissues obtained at autopsy from babies dying of malnutrition (Waterlow, 1956). No information has been found in the literature on the effect of malnutrition on the DNA content of muscle. The experiments reported here were therefore extended to compare the response of muscle during refeeding with that of liver.

A subsidiary object of this work was to find the simplest method for routine measurements of DNA in small samples of tissue (dry weight about $10 \mathrm{mg}$ ). For this reason the analytical methods used were not the same in all the experiments.

\section{EXPERIMENTAL}

\section{Animals and procedure}

Albino rats of a strain obtained from the National Institute for Medical Research were weaned at $2 \mathrm{I}$ days, and the litters divided into two. One group, the controls, were put on a stock diet containing $18 \%$ protein; the other group were put on a simulated Jamaican diet which is low in protein (see below). In earlier experiments rats were kept for varying periods of up to 7 weeks on this diet, and then either killed or put back on to the stock diet. In later experiments the time on the 'Jamaican' diet was standardized at 28-29 days; at that point two rats of each litter were killed. The remainder were put on to the stock diet, and killed at intervals. Except when measurements of food intake were being made the rats were not kept in individual cages.

The 'Jamaican' diet was modified from that described by Feng \& Kean (1955), which was based on the dietary surveys of Rhodes (1952). Its composition is shown in Table I. The yams and green bananas were peeled, boiled, mashed, dried in a 
steam oven at about $60^{\circ}$, and ground to a powder. The protein content of this diet, calculated as $\mathrm{N} \times 6.25$, is $6.4 \%$. The vitamin content is not known.

Three main experiments and several pilot trials were done, involving in all 160 animals. For the measurements on liver, samples were taken weighing $200-400 \mathrm{mg}$. For those on muscle, duplicate samples weighing about $50 \mathrm{mg}$ were taken from the thighs. In a final experiment (Exp. 4) the gastrocnemii muscles were dissected out intact and weighed to give an estimate of the total muscle mass.

Table I. Composition and analysis of 'Gamaican' diet

\begin{tabular}{|c|c|c|c|c|}
\hline \multicolumn{3}{|c|}{ Composition } & \multirow{2}{*}{\multicolumn{2}{|c|}{ Analysis }} \\
\hline \multirow[b]{2}{*}{ Foodstuff } & \multirow{2}{*}{$\begin{array}{c}\text { Protein* } \\
\text { content } \\
(\%)\end{array}$} & \multirow[b]{2}{*}{$\begin{array}{l}\text { Amount } \\
(\mathrm{g} / \mathrm{r} 00 \mathrm{~g})\end{array}$} & & \\
\hline & & & Constituent & $\begin{array}{l}\text { Amount } \\
\text { (g/100 g }\end{array}$ \\
\hline Full-cream dried milk & 26 & $7 \cdot 5$ & Water & $7 \cdot 4$ \\
\hline \multirow[t]{2}{*}{ Dried powdered yellow yam } & $4 \cdot 25$ & 20 & Fat & $8 \cdot 5$ \\
\hline & & & Carbohydrate & $73 \cdot 6$ \\
\hline Dried powdered green banana & $3 \cdot 55$ & $22 \cdot 5$ & Protein* & $6 \cdot 4$ \\
\hline Refined maize meal & $7 \cdot 5$ & 30 & Ash & $2 \cdot 1$ \\
\hline Brown sugar & $\circ$ & 20 & Fibre & $2 \cdot 0$ \\
\hline
\end{tabular}

\section{Analytical methods}

The methods used for nucleic-acid estimation were based on a combination of the methods of Schneider (I945) and of Schmidt \& Thannhauser (I945), similar to that proposed by Logan, Mannell \& Rossiter (I952). The aim was, if possible, to base the measurements on ultraviolet absorption, for the sake of simplicity and because this method is more sensitive than the colour reactions for pentoses, and more specific than the estimation of phosphorus.

Method I (Exp. I ; liver only). The tissue was homogenized in $95 \%(\mathrm{v} / \mathrm{v})$ ethyl alcohol, because this protein precipitant does not hydrolyse nucleic acids. The precipitate was suspended in $\mathrm{N}-\mathrm{NaOH}$, and stood at room temperature for $\mathrm{I} \frac{1}{2} \mathrm{~h}$. In preliminary experiments these conditions were found to be adequate for the hydrolysis of ribonucleic acid (RNA). After standing, to $2 \mathrm{ml}$. of the $\mathrm{NaOH}$ solution were added $0.8 \mathrm{ml}$. $6 \mathrm{~N}-\mathrm{HCl}$ and $0.8 \mathrm{ml} .30 \%(\mathrm{w} / \mathrm{v})$ trichloroacetic acid (TCA) in the cold. RNA was estimated in the supernatant fluid, after suitable dilution, by the absorption at $263 \mathrm{~m} \mu$. The precipitate was washed twice with cold $5 \%$ TCA, and extracted with $2 \mathrm{ml} .5 \%$ TCA for $15 \mathrm{~min}$ at $90^{\circ}$, according to the method of Schneider (1945). A portion of the extract was diluted twenty-five times with water, and the DNA content measured by the absorption at $263 \mathrm{~m} \mu$. In calculating the results the factors used were: for DNA, molar extinction coefficient $=9000$; for RNA, molar extinction coefficient $=9740$. These were derived from commercial samples of DNA and RNA that were used in the previous investigation (Waterlow \& Weisz, 1956).

In the early experiments the $\mathrm{N}$ content of the residue after DNA extraction was estimated, to give the protein content of the liver sample. In the course of the work it was found that an appreciable fraction of the protein was hydrolysed on standing in 
$\mathrm{NaOH}$, and was no longer precipitated with the DNA. For this reason the total nitrogen content was measured in separate samples of liver that had been dried, fatextracted and preserved. Such measurements give an estimation of the protein content that is too high by the amount of non-protein nitrogen. Thereafter a portion of the $\mathrm{NaOH}$ solution was taken for estimation of protein $\mathrm{N}$.

Method 2 (Exp. 2; liver and muscle). This method was essentially the same as method I except that the tissue was placed overnight in $\mathrm{N}-\mathrm{NaOH}$, and $\mathrm{r} \cdot 6 \mathrm{~N}$-perchloric acid (PCA) was used for precipitating the DNA and protein. DNA was extracted by heating in $0.8 \mathrm{~N}-\mathrm{PCA}$ at $80^{\circ}$ for $10 \mathrm{~min}$. In calculating the results the following extinction coefficients were used: for DNA i I,900; for RNA 10,490. These factors were derived from measurements on semi-purified DNA and RNA prepared by extracting muscle powder with boiling $10 \% \mathrm{NaCl}$ (Davidson \& Smellie, 1952).

This modification was adopted because PCA, like TCA, has a negligible absorption in the ultraviolet, and is therefore more suitable for work on the micro-scale, where volumes must be kept small. The method was abandoned because it was found that PCA extracts from muscle, and sometimes from liver, contain substances other than nucleotides-probably degradation products of protein - that absorb in the ultraviolet and cause a flattening of the absorption curve (Fig. I). In extreme cases the peak of nucleotide absorption at $260-265 \mathrm{~m} \mu$ may be obliterated. In an attempt to circumvent the difficulty a number of other acids were tried as extracting media, but without success.

A portion of the $\mathrm{NaOH}$ solution was used for measurement of protein $\mathrm{N}$.

Method 3 (Exp. 3; muscle only). The muscle was homogenized in the cold in $0.8 \mathrm{~N}-$ $\mathrm{HNO}_{3}$, so that electrolytes could be measured if necessary. The precipitate was washed and extracted with $0.8 \mathrm{~N}-\mathrm{PCA}$. The DNA content of the extract was measured by the diphenylamine reaction, as modified by Burton (1956).

The residue was suspended in $0.5 \mathrm{ml} .0 .5 \mathrm{~N}-\mathrm{NaOH}$ and allowed to stand overnight at room temperature. The undissolved material was taken to be collagen. The solution was centrifuged, the supernatant liquid removed, and the collagen residue washed twice with water, the washings being added to the supernatant liquid. Non-collagen nitrogen was estimated by micro-Kjeldahl in the combined supernatant liquid and washings, collagen $\mathrm{N}$ in the residue.

Measurement of DNAP per nucleus. A sample of liver was homogenized in $2 \%$ citric acid in the cold, filtered through nylon fabric, and centrifuged. The deposit was washed twice with $0.2 \%$ citric acid, suspended in a suitable volume, and the nuclei counted in duplicate in a haemocytometer chamber. To a portion of the suspension $\mathrm{KOH}$ was added to final $\mathrm{N}$ concentration; after standing, the DNA was precipitated and extracted with PCA, as in method 2.

Carcass analysis. In one group of rats the carcass, except for the liver, was dried to constant weight in the oven at $100^{\circ}$. It was then homogenized in a blender with benzene, and extracted with several more changes of benzene. The powder was dried in the oven and weighed. Water content and fat content were calculated by difference. The dry fat-free powder was dissolved in about $100 \mathrm{ml}$. $\mathrm{N}-\mathrm{NaOH}$ by standing overnight in the oven at $100^{\circ}$. Solution was complete except for fragments of bone. The 
volume was made to $25^{\circ} \mathrm{ml}$, and portions were taken for measurement of nitrogen and potassium. $\mathrm{K}$ was measured by flame photometry, with $\mathrm{N}-\mathrm{NaOH}$ as a blank. This treatment with alkali was necessary because it was not found possible to obtain completely homogeneous samples of the carcass powder.

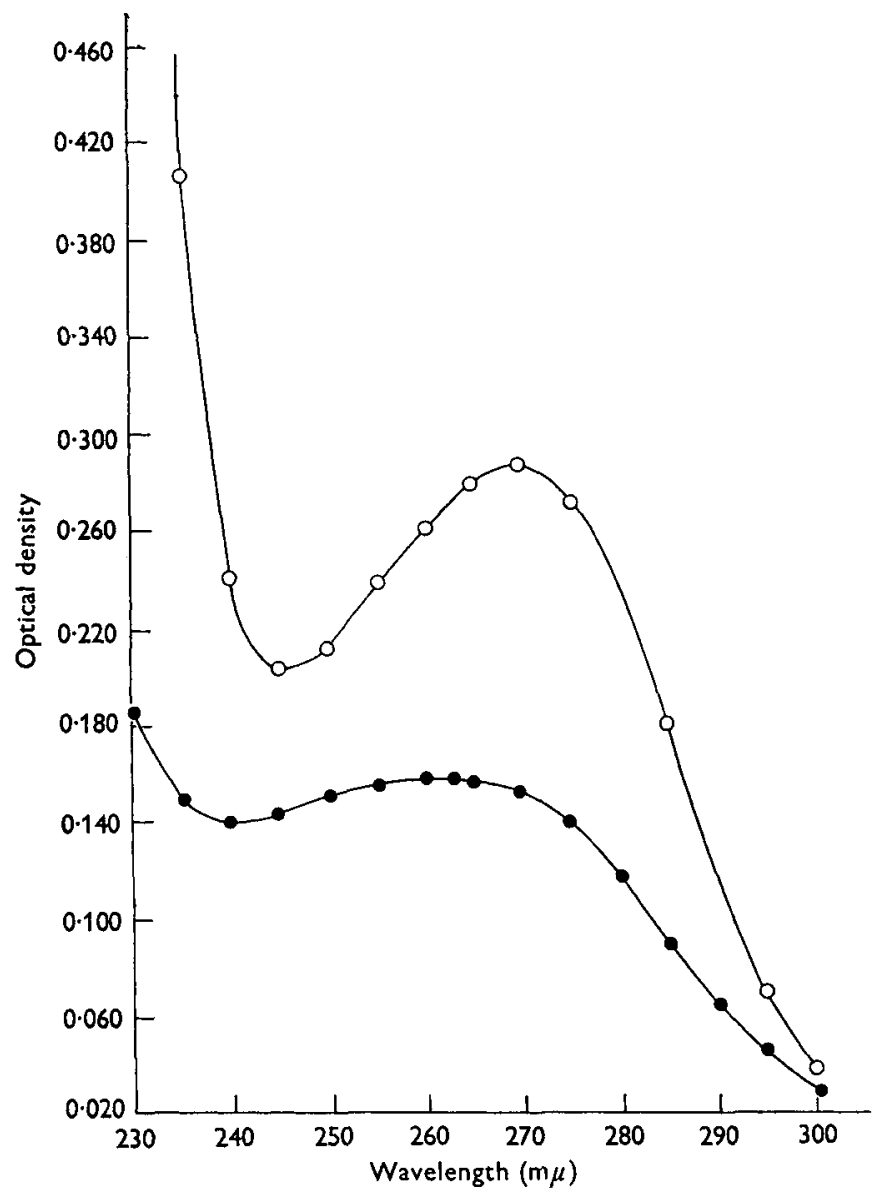

Fig. I. Ultraviolet-absorption curves of rat-muscle DNA, unpurified and partially purified by extraction with $10 \% \mathrm{NaCl}$. -0 , semi-purified muscle DNA (tissue extracted with 10\% $\mathrm{NaCl}$ ); - - perchloric-acid extract (no extraction with $\mathrm{NaCl}$ ).

\section{RESULTS}

Body-weight and general condition. Fig. 2 shows that on the 'Jamaican' diet the rats maintained an almost constant body-weight. They became progressively more apathetic, but developed no specific signs of deficiency, such as oedema or dermatosis. How long they would have survived is not known, since no rats were kept on the diet for more than 7 weeks.

At autopsy the organs showed no gross pathological changes. In six rats which had been kept on the 'Jamaican' diet for 42 days, and in five rats that were transferred to the stock diet, the whole carcass (excluding the liver) was dried and, after the fat had 
been extracted, powdered. The results of nitrogen and potassium estimations are shown in Table 2. From these figures it appears that the gross body composition of these malnourished rats was normal, which is in agreement with the findings of Widdowson \& McCance (1957) and of Stanier (1957). There was no change in the ratio of potassium to nitrogen.

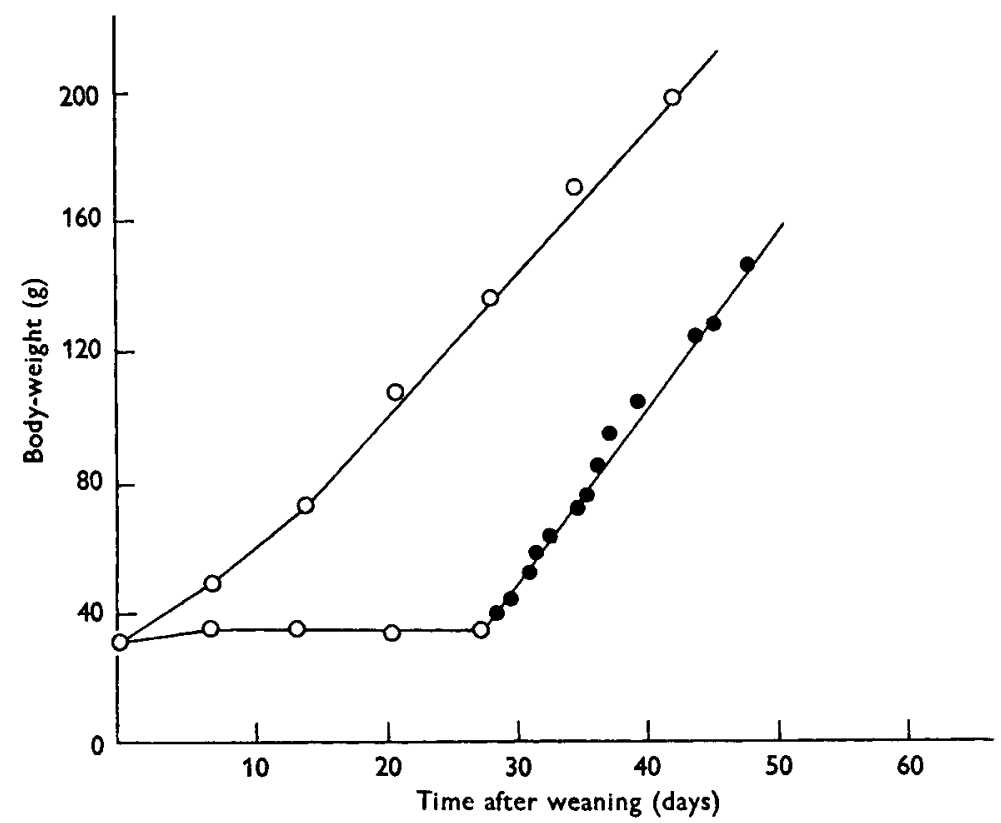

Fig. 2. Exps. I and 2. Body-weight of male rats fed on a stock diet from weaning (upper curve); a 'Jamaican' diet from weaning (lower curve, $0_{-}$); or the stock diet after 28 days on the 'Jamaican' diet (lower curve, -—). (See p. 75.)

When the depleted rats were put back on to the stock diet containing i $8 \%$ protein, there was an immediate and rapid increase in weight which continued until the rat had nearly reached the normal weight for its age. The question whether rats that have been depleted after weaning, and then put on to an adequate diet, behave normally in

Table 2. Pilot experiment. Mean values with their standard errors for water, fat, nitrogen, potassium and sodium content of the carcass in two groups of weanling rats fed on a 'Famaican' diet for 28 days. One group was killed at the end of this depletion period, the other was fed on a stock diet for 3-7 days

\begin{tabular}{|c|c|c|c|c|c|}
\hline $\begin{array}{l}\text { No. } \\
\text { of } \\
\text { rats }\end{array}$ & $\begin{array}{l}\text { Water } \\
\text { (percentage of } \\
\text { wet weight) }\end{array}$ & $\begin{array}{l}\text { Fat } \\
\text { (percentage of } \\
\text { wet weight) }\end{array}$ & $\begin{array}{l}\text { Nitrogen } \\
\text { (g/100 } g \\
\text { fat-free } \\
\text { dry weight) }\end{array}$ & $\begin{array}{c}\text { Potassium } \\
\text { (m-equiv./100 g } \\
\text { fat-free } \\
\text { dry weight) }\end{array}$ & $\begin{array}{c}\text { Muscle sodium } \\
\text { (m-equiv./100 g } \\
\text { fat-free } \\
\text { dry weight) }\end{array}$ \\
\hline $\begin{array}{l}6 \text { 'Jamaican' diet for } \\
28 \text { days }\end{array}$ & $68 \cdot 3 \pm 0 \cdot 45$ & $8.7 \pm 0.56$ & $10.6 \pm 0.19$ & $35.9 \pm 0.52$ & $10.7 \pm 0.49$ \\
\hline $\begin{array}{l}5 \text { 'Jamaican' diet for } \\
28 \text { days then stock } \\
\text { diet for } 3-7 \text { days }\end{array}$ & $72 \cdot 0 \pm 0.425$ & $4.8 \pm 0.84$ & $9.65 \pm 0.35$ & $33 \cdot 3 \pm r \cdot 28$ & $18 \cdot 0 \pm I \cdot 84$ \\
\hline
\end{tabular}

The differences in water, fat and sodium content are significant $(P<0.01)$. 
later life, e.g. in gain in weight, or reproductive performance, is one for future experiment. Although the number of rats was small, the figures in Tables 2 and 3 suggest that during the first 3 days after transference to the stock diet an excessive amount of water was retained, and perhaps also of sodium. Thereafter nitrogen and water were retained in the normal ratio.

Table 3. Pilot experiment. Increases in water and nitrogen content of the carcass in weanling rats fed on a stock diet after 28 days on a 'Famaican' diet

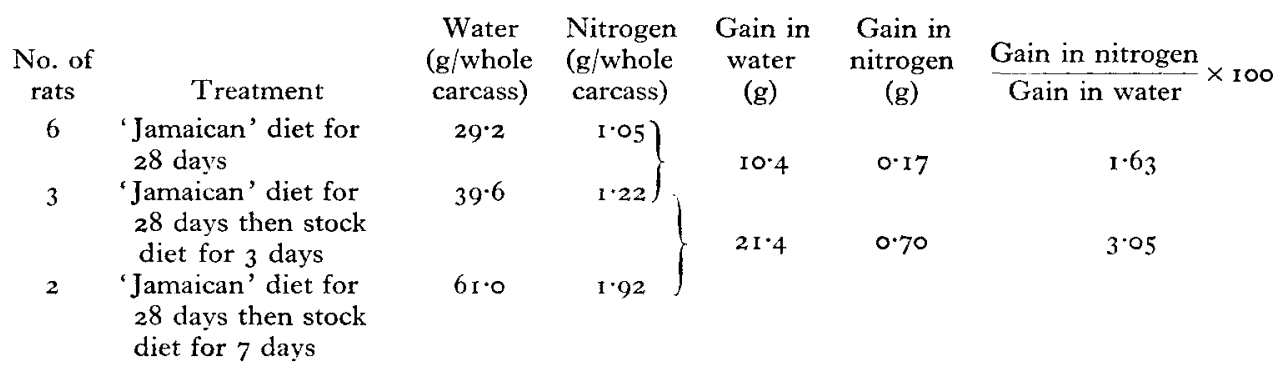

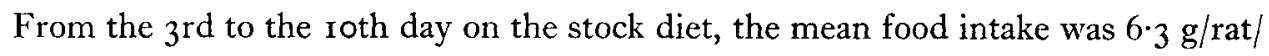
day, and the mean weight gain $5.5 \mathrm{~g} /$ day, which means that virtually all the nitrogen eaten must have been retained. Such an immediate and efficient utilization of food was surprising, since at the end of the depletion period the pancreas was atrophic (Fig. 3), and it is probable that the same applies to the gut mucosa.

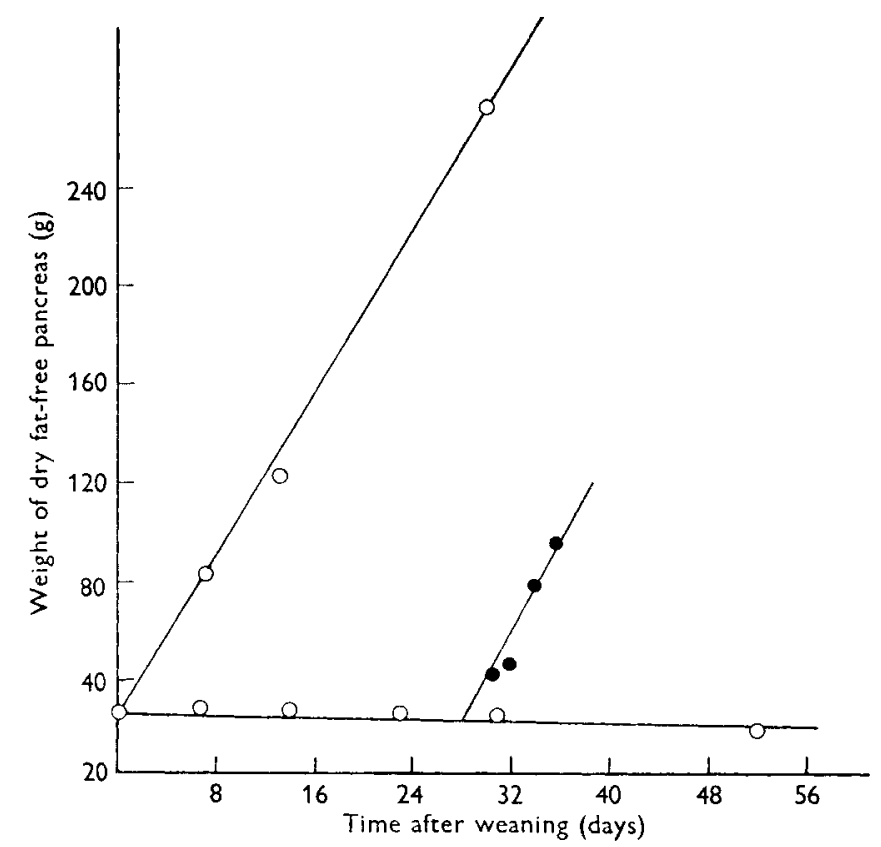

Fig. 3. Exp. I. Weight of pancreas in rats fed on a stock diet from weaning (upper curve); a 'Jamaican' diet from weaning (lower curve, $\mathrm{O}_{-}-\mathrm{O}_{\text {) }}$; or the stock diet after 28 days on the 'Jamaican' diet (lower curve, ). (See p. 75.) 
The rat evidently responds to treatment much more easily than man. Out of forty-nine depleted rats that were offered the stock diet, only five failed to respond immediately.

Liver. The 'Jamaican' diet does not produce a fatty liver. After 4-5 weeks on the diet there was no histological abnormality, except an apparent excess of glycogen. This excess has been noted by Balfour (1954) in the livers of rats on a cassava diet. In the depleted rats the water content of both liver and pancreas was increased (Table 4) -a finding that was unexpected, since there was no increase in the water content of the body as a whole. A similar increase in the proportion of water to nitrogen was found in the livers of human infants dying of malnutrition (Waterlow, Bras \& De Pass, 1957). Many of these infants, however, were oedematous, whereas the rats were not.

Table 4. Exp. r. Mean values with their standard errors for water content of the liver and pancreas of weanling rats fed for varying periods on a stock diet (A), a' 'Famaican' $\operatorname{diet}(B)$, or a stock diet after 28 days on the 'Gamaican' diet $(C)$

$\begin{array}{lcc}\text { Treatment } & \begin{array}{c}\text { Liver } \\ \text { (g/g protein) }\end{array} & \begin{array}{c}\text { Pancreas } \\ \text { (g/g dry fat-free } \\ \text { solids) }\end{array} \\ \begin{array}{cc}\text { (A) Stock diet for } 0-33 \text { days from } \\ \text { weaning }\end{array} & 4.57 \pm 0.24 \text { (12) } & 4.07 \pm 0.14 \text { (14) } \\ \text { (B) 'Jamaican' diet for } 7-52 \text { days } & 6.14 \pm 0.17 \text { (14) } & 6.41 \pm 0.32 \text { (14) } \\ \begin{array}{l}\text { from weaning } \\ \text { (C) 'Jamaican' diet for } 28 \text { days } \\ \text { from weaning, then stock diet } \\ \quad \text { for } 3-8 \text { days }\end{array} & 4.64 \pm 0.18 \text { (7) } & 4.80 \pm 0.21 \text { (8) }\end{array}$

Figures in parentheses are the number of rats.

The water content of both liver and pancreas was significantly raised $(P=<0.01)$ in the group on treatment $\mathrm{B}$ compared with either the group on treatment $\mathrm{A}$ or the group on treatment $\mathrm{C}$.

Fig. 4 shows that the liver weight, like the body-weight, remained almost constant for as long as the animals were kept on the diet. On refeeding on the stock diet the liver weight increased very rapidly, at about twice the rate found during normal growth.

Total liver protein and total liver DNAP followed much the same pattern (Figs. 5 and 6). In the two experiments on the liver there was a large difference in the calculated values for liver DNAP in groups of rats that had received the same treatment, e.g. for normal rats 28-30 days from weaning:

Exp. I (TCA extraction): $\mathrm{DNAP}=24^{\circ} 4 \mu \mathrm{g} / \mathrm{I} 00 \mathrm{mg}$ wet weight;

Exp. 2 (PCA extraction): DNAP $=\mathrm{I}_{4} \cdot 0 \mu \mathrm{g} / \mathrm{I} 00 \mathrm{mg}$ wet weight.

The reason for this difference lies in the different factors and standards used for calculating the results (see p. 76). In both experiments, however, the changes were the same in direction and degree. In order to allow the results to be plotted together they have therefore been expressed as a percentage of the values found at weaning.

Figs. 5 and 6 do not bring out a point that is better seen when the results are expressed as ratios. In the animals on the 'Jamaican' diet total liver protein was reduced more than the body-weight, whereas total liver DNAP increased slightly 
(Table 5 , columns 3 and 4 ). The result of these two processes is that on the diet the ratio N:DNAP fell to about half its normal level. On refeeding this normal level was very rapidly restored.

Our data do not allow a detailed analysis of the time course of these events. On refeeding for the first few days the formation of new protein seems to take precedence over that of DNA, since within $4^{-6}$ days the ratio N:DNAP rose to normal. In the first experiment there was evidence of a lag in DNA formation. The increase in total liver DNA was not very great until the 6th day: at that point, but not until then, histological examination showed large numbers of mitoses.

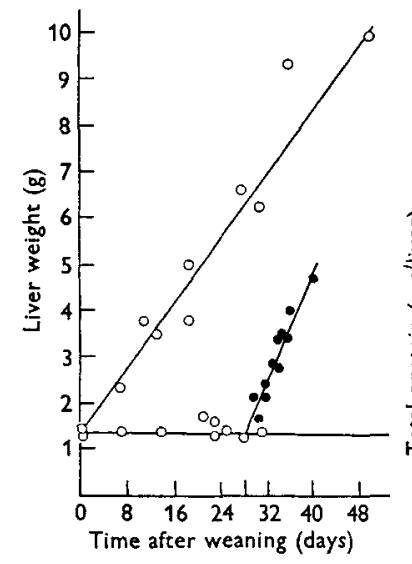

Fig. 4

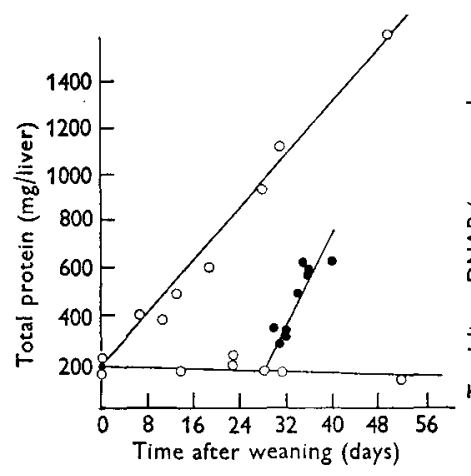

Fig. 5

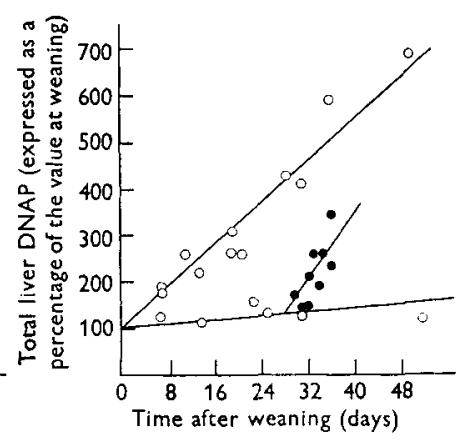

Fig. 6

Fig. 4. Exp. 1. Weight of liver in rats fed on a stock diet from weaning (upper curve); a 'Jamaican' diet from weaning (lower curve, $0-0$ ); or the stock diet after 28 days on the 'Jamaican' diet (lower curve, - - ). (See p. 75.)

Fig. 5. Exps. I and 2. Total liver protein in rats fed on a stock diet from weaning (upper curve); a 'Jamaican' diet from weaning (lower curve, $0_{-}$) ; or the stock diet after 28 days on the 'Jamaican' diet (lower curve, (See p. 75.)

Fig. 6. Exps. I and 2. Total liver DNAP, as a percentage of the total at weaning, in rats fed on a stock diet from weaning (upper curve); a 'Jamaican' diet from weaning (lower curve, $\bigcirc-0$ ); or the stock diet after 28 days on the 'Jamaican' diet (lower curve, $-\bullet$ ). (See p. 75.)

Table 5 shows also that, in agreement with the findings of previous workers (Thomson et al. 1953), RNA followed the same pattern as nitrogen.

In twenty-five rats measurements were made of the average DNAP content per liver-cell nucleus. The results in Table 5 show an increase during normal growth of the same order as that found by Jacob et al. (1954). The deficient diet arrested the normal increase in DNAP content per nucleus, which agrees with the result of Fukuda \& Sibatani (1953), but not with that of Ely \& Ross (195I). It is apparent from Table 5 that the increase in liver DNA that occurs on refeeding results mainly from a multiplication of cells. The total liver DNAP was trebled after I 2 days of refeeding, whereas the DNAP/nucleus increased only by a factor of $\mathrm{I} \cdot \mathbf{2}$.

Muscle. Since it would be very difficult to measure the whole muscle mass of the animal, two muscles were taken as samples, the gastrocnemius and the quadriceps femoris. These were dissected out and weighed in a small group of rats. Fig. 7 shows 


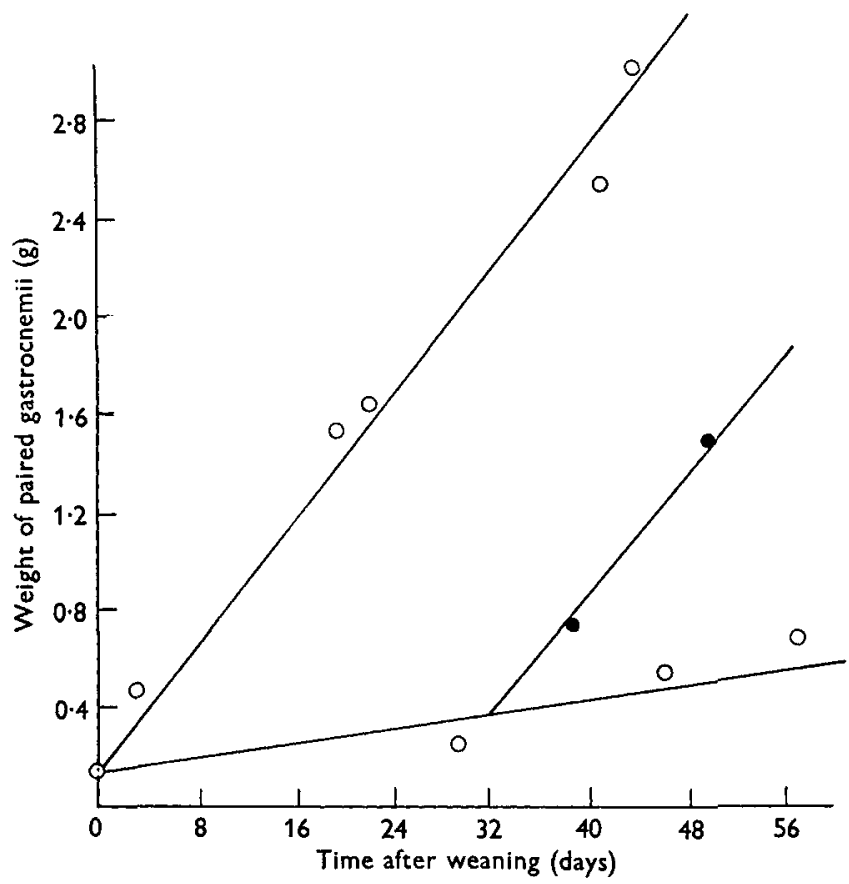

Fig. 7. Exp. 4. Weight of paired gastrocnemii in male rats fed on a stock diet from weaning (upper curve); a 'Jamaican' diet from weaning (lower curve, $\mathrm{O}-\mathrm{O}$ ); or the stock diet after 28 days on the 'Jamaican' diet (lower curve,

). (See p. 75.)

Table 5. Exp. I. Mean values for total protein and DNAP content of liver in weanling rats fed on a stock diet, a 'Gamaican' diet, or the stock diet after 28 days on the 'Gamaican' diet

\begin{tabular}{|c|c|c|c|c|c|c|}
\hline $\begin{array}{l}\text { No. } \\
\text { of } \\
\text { rats }\end{array}$ & Treatment & $\begin{array}{c}\text { Protein } \\
\text { (mg/100 g } \\
\text { body-weight) }\end{array}$ & $\begin{array}{c}\text { DNAP } \\
\text { (mg/loo g } \\
\text { body-weight) }\end{array}$ & $\begin{array}{l}\text { Ratio, } \\
N: \text { DNAP }\end{array}$ & $\begin{array}{c}\text { Ratio, } \\
\text { RNAP: DNAP }\end{array}$ & $\begin{array}{c}\text { DNAP/ } \\
\text { liver cell } \\
\text { nucleus* } \\
\left(\mu \mathrm{g} \times 10^{-7}\right)\end{array}$ \\
\hline 3 & $\begin{array}{l}\text { At weaning } \\
\text { Stock diet for: }\end{array}$ & 49 & $1 \cdot 23$ & 66 & - & $7 \cdot 1(2)$ \\
\hline 2 & 7 days & 77 & $x \cdot 26$ & 98 & - & - \\
\hline 2 & 13 days & 66 & $1 \cdot 05$ & 99 & 一 & - \\
\hline 2 & I 9 days & 80 & $I \cdot 24$ & 103 & 4.50 & $8 \cdot 9(2)$ \\
\hline 5 & $29^{-}-33$ days & 89 & $1 \cdot 22$ & 119 & $5 \cdot 65$ & $8 \cdot 85(4)$ \\
\hline & 'Jamaican' diet for: & & & & & \\
\hline 3 & 7 days & 68 & $1 \cdot 68$ & 67 & 一 & - \\
\hline 3 & 14 days & 57 & $I^{\cdot} 5^{2}$ & 59 & - & 一 \\
\hline 8 & $23-25$ days & 62 & $1 \cdot 82$ & 55 & $2 \cdot 60$ & $6 \cdot 4(2)$ \\
\hline 2 & 31 days & 59 & $\mathbf{I} 79$ & 52 & $2 \cdot 8 \mathrm{I}$ & - \\
\hline 2 & 52 days & 44 & $1 \cdot 72$ & 39 & 一 & - \\
\hline & $\begin{array}{l}\text { 'Jamaican' diet for } \\
28 \text { days, then refed for: }\end{array}$ & & & & & \\
\hline 2 & 2 days & - & - & - & - & $6 \cdot 35(2)$ \\
\hline 4 & $3-4$ days & 84 & $I \cdot 5 I$ & 88 & $4 \cdot 85$ & $7 \cdot 0(2)$ \\
\hline 7 & 6-8 days & 98 & $I \cdot 43$ & 113 & 5.40 & $7 \cdot \circ(4)$ \\
\hline
\end{tabular}

* Values from Exp. 2. Figures in parentheses are the numbers of determinations. 
the weight of paired gastrocnemii in male rats. The quadriceps femoris followed an almost identical curve. In the discussion that follows it is assumed that these muscles give a fair representation of changes in the whole muscle mass.

On the deficient diet and after transference to the stock diet muscle weight followed the same general pattern as liver weight and body-weight, except that recovery seemed to be slower in the early stages of refeeding.

The DNA content of muscle was lower than that of liver. In order to obtain a figure which would be affected as little as possible by sampling error, and which would be comparable to those obtained for liver by other workers, a pooled sample was taken from a group of normal rats 28 days after weaning. The DNAP content, measured by the Schmidt-Thannhauser method was $6.85 \mu \mathrm{g} / \mathrm{I}$ oo $\mathrm{mg}$ wet weight. It is about one-quarter of the value for liver obtained by Thomson et al. (1953), using the same method.

In the two main experiments on muscle, as in those on liver, the two different methods used did not give the same absolute results; however, the changes produced by depletion and refeeding were closely similar in the two experiments. The results have therefore been expressed as percentages of the levels at weaning, and combined in Table 6. The last column of this table was obtained by multiplying the DNAP content by the weight of the gastrocnemii, as a sample of the whole muscle mass. These figures show that the formation of new DNA occurred more slowly in muscle than in liver. In liver (Fig. 6) total DNA was trebled in about 12 days, whereas in muscle this increase took 3 weeks.

The changes in the ratio N:DNAP are summarized in Table 7. The figures for total $\mathrm{N}$ do not tell the whole story. On the 'Jamaican' diet there was a great increase in collagen, both relative and absolute (Table 8). This finding means that the noncollagen nitrogen $(\mathrm{NCN})$ was much more severely reduced than appears from the

Table 6. DNAP content of muscle in weanling rats fed on a stock diet, a 'Gamaican' diet, or the stock diet after 28 days on the 'Gamaican' diet

\begin{tabular}{|c|c|c|c|}
\hline \multirow[b]{2}{*}{ Treatment } & \multirow{2}{*}{$\begin{array}{l}\text { Muscle weight, } \\
\text { paired } \\
\text { gastrocnemii } \\
\text { (g) }\end{array}$} & \multicolumn{2}{|c|}{$\begin{array}{l}\text { DNAP content of muscle } \\
\text { (expressed as a percentage of } \\
\text { the value at weaning) }\end{array}$} \\
\hline & & $\begin{array}{l}\mu \mathrm{g} / 100 \mathrm{mg} \\
\text { wet weight }\end{array}$ & Total \\
\hline At weaning & 0.146 & 100 & 100 \\
\hline \multicolumn{4}{|l|}{ Stock diet for: } \\
\hline $28-29$ days & I.24 & 50 & 425 \\
\hline $38-40$ days & $2 \cdot 23$ & 37 & 560 \\
\hline $48-5$ I days & 2.I I & $33 \cdot 5$ & 475 \\
\hline $\begin{array}{l}\text { 'Jamaican' diet for } \\
28-29 \text { days }\end{array}$ & 0.26 & 71 & 125 \\
\hline \multicolumn{4}{|c|}{$\begin{array}{l}\text { 'Jamaican' diet for } 28 \text { days, } \\
\text { then stock diet for: }\end{array}$} \\
\hline IO-I I days & 0.72 & 46 & 226 \\
\hline $20-21$ days & $I \cdot 56$ & 35 & 375 \\
\hline
\end{tabular}

The values for muscle weight (column 2) were obtained in Exp. 4 (two rats in each group). The figures for DNAP content per unit wet weight (column 3) are the combined results of Exps. 2 and 3 (four rats in each group). The figures for total muscle DNAP (last column) are calculated from those in the preceding columns. 
figures for total nitrogen. The NCN per unit DNAP may be taken as a measure of the cytoplasmic protein of the cell. On the 'Jamaican' diet this index was reduced to about a quarter of the value found in normal rats of the same age.

Table 7. Exp. 3. Protein and DNAP content of muscle in weanling rats fed on a stock diet, a 'Famaican' diet, or the stock diet after 28 days on the 'Gamaican' diet

\begin{tabular}{|c|c|c|c|c|c|c|c|}
\hline \multirow[b]{2}{*}{ Treatment } & \multirow[b]{2}{*}{$\begin{array}{l}\text { No. } \\
\text { of } \\
\text { rats }\end{array}$} & \multirow[b]{2}{*}{$\begin{array}{c}\text { Total } \mathrm{N} \\
\text { (mg/100 } \mathrm{mg} \\
\text { wet weight) }\end{array}$} & \multirow[b]{2}{*}{$\begin{array}{l}\text { Collagen } N \\
\text { (as percent- } \\
\text { age of } \\
\text { total } N \text { ) }\end{array}$} & \multirow[b]{2}{*}{$\begin{array}{c}\text { Non- } \\
\text { collagen } \mathrm{N} \\
\text { (mg/Ioo mg } \\
\text { wet weight) }\end{array}$} & \multicolumn{3}{|c|}{$\begin{array}{l}\text { Value expressed as a percentage of } \\
\text { the value at weaning }\end{array}$} \\
\hline & & & & & $\begin{array}{c}\text { DNAP } \\
(\mu \mathrm{g} / 100 \mathrm{mg} \\
\text { wet weight })\end{array}$ & $\begin{array}{l}\text { Total N } \\
\text { (mg/mg } \\
\text { DNAP) }\end{array}$ & $\begin{array}{l}\text { Non- } \\
\text { collagen N* } \\
\text { (mg/mg } \\
\text { DNAP) }\end{array}$ \\
\hline At weaning & 2 & $2 \cdot 02$ & - & - & 100 & 100 & roo \\
\hline Stock diet for: & & & & & & & \\
\hline 28 days & 2 & $2 \cdot 11$ & - & 一 & $49 \cdot 5$ & 212 & $\longrightarrow$ \\
\hline $3^{8}$ days & 2 & $2 \cdot 21$ & $3 \cdot I$ & $2 \cdot 14$ & 32 & 342 & $34^{\circ}$ \\
\hline 48 days & 2 & $2 \cdot 20$ & $4 \cdot 0$ & $2 \cdot 11$ & 30 & 362 & 355 \\
\hline $\begin{array}{l}\text { 'Jamaican' diet for } \\
28 \text { days }\end{array}$ & 2 & $1 \cdot 62$ & $34^{\cdot 1}$ & $x \cdot 07$ & $5^{8}$ & I 39 & 94 \\
\hline Refed for: ro days & 2 & $1 \cdot 82$ & $2 \mathrm{I} \cdot \mathrm{I}$ & $I \cdot 44$ & $4 \mathrm{I}$ & 219 & 179 \\
\hline 20 days & 2 & I'97 & $10 \cdot 5$ & $I \cdot 77$ & 27 & 362 & 334 \\
\hline
\end{tabular}

* The collagen samples from the rats at weaning and on the stock diet for 28 days were accidentally lost. The assumption has therefore been made that at weaning collagen $\mathrm{N}=3 \%$ of total $\mathrm{N}$.

Table 8. Exp. 3. Collagen content of muscle in weanling rats fed on a stock diet, a 'Gamaican' diet, or the stock diet after 28 days on the 'Gamaican' diet

$\begin{array}{lccc}\text { No. of } & \begin{array}{c}\text { Weight of } \\ \text { paired } \\ \text { Treatment }\end{array} & \begin{array}{c}\text { Total } \\ \text { gastrocnemii (g) }\end{array} & \begin{array}{c}\text { collagen } \mathbf{N} \\ (\mathrm{mg})\end{array} \\ \text { At weaning } & 2 & 0.146 & 0.09^{*} \\ \text { Stock diet for 38 days } & 2 & 2.23 & 1.53 \\ \text { 'Jamaican' diet for 28 days } & 2 & 0.26 & 1.44 \\ \text { Refed for: IO days } & 2 & 0.72 & 2.76 \\ & 2 & 1.56 & 2.91\end{array}$

* This value has been calculated on the assumption that collagen $\mathrm{N}=3 \%$ of total muscle $\mathrm{N}$.

\section{DISCUSSION}

Three points of interest emerge from these results.

(I) As was expected, the deficient diet caused a greater fall in the ratio of protein to DNA in muscle than in liver. In clinical work, therefore, analysis of muscle would probably give a better indication of the degree of protein depletion than analysis of liver, at least when malnutrition or growth arrest has been going on for some time.

The degree of muscle atrophy is best shown when account is taken of the collagen content of the tissue. The values in Table 8 suggest, if the samples analysed were representative, that the total amount of collagen throughout the body must have increased considerably during the period on the diet. Collagen, in other words, continued to grow in spite of the deficiency. This finding fits in with the clinical impression that growth went on in the skeleton and the skin. Unfortunately, no objective measurements were made to test it. In Stanier's (1957) experiments the skin was analysed, but no figures are given for its weight. Many years ago Nobécourt 
(I916) emphasized the same phenomenon in human medicine, when he wrote of the malnourished child in whom 'l'enveloppe est trop grande pours le corps qu'elle renferme'.

This dissociation of collagen and cellular proteins in their response to a deficient diet re-emphasizes the point made by Neuberger, Perrone \& Slack (1951) that from the metabolic point of view tissues are mixtures of components with different turnover rates. It would be interesting to know whether there is a similar dissociation between the different fractions of the non-collagen muscle protein. This point is being investigated.

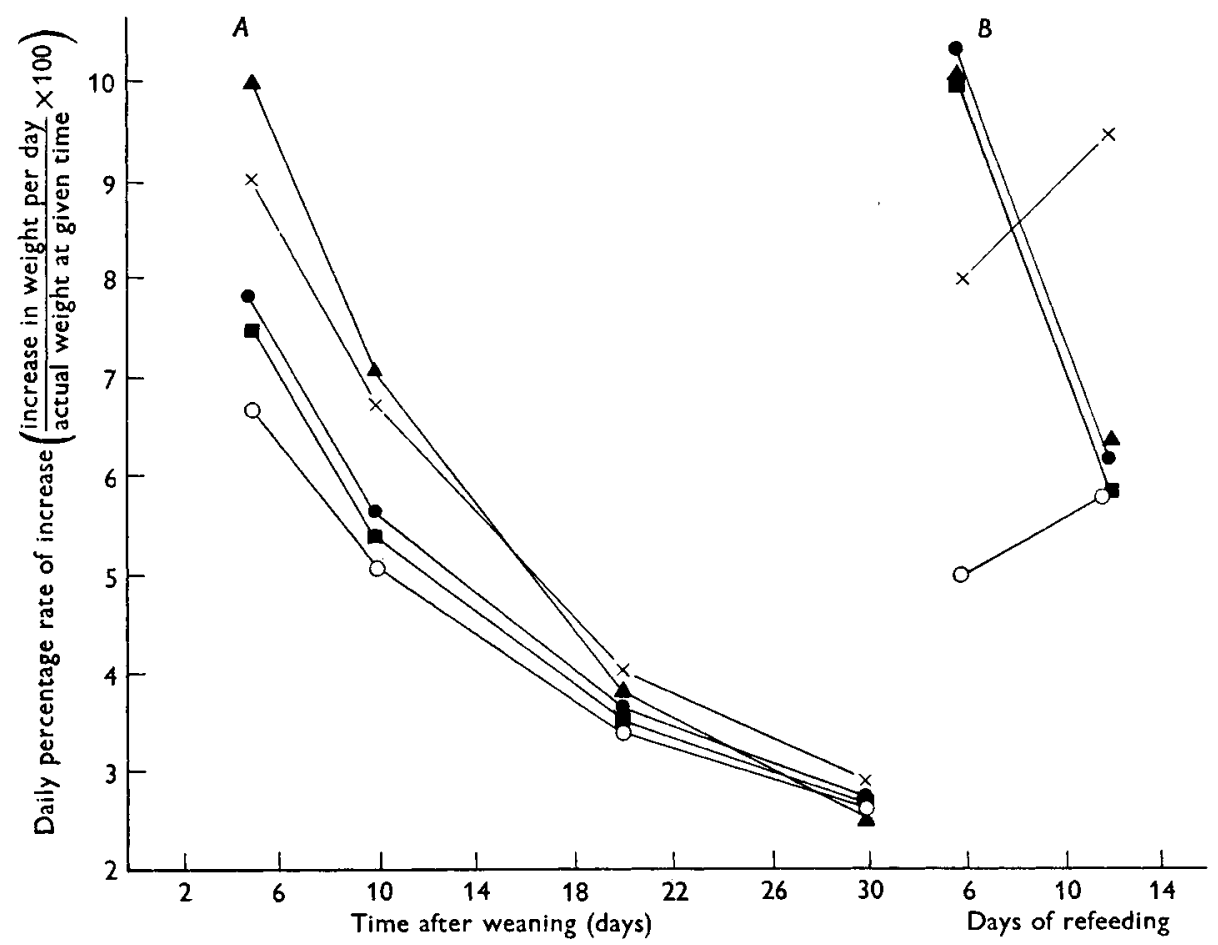

Fig. 8. Rate of increase in body-weight ( $-\infty)$, liver weight $(\bullet-\bullet)$, muscle weight $(\times-\times)$, total liver DNAP (- $)$, and 'total' muscle DNAP $\left(0_{-}-\infty\right)$ in rats $(A)$ during normal growth on a stock diet and $(B)$ during accelerated growth on the stock diet after 28 days on a 'Jamaican' diet.

(2) The results show that, gram for gram, muscle can form new tissue as fast as liver, and new DNA nearly as fast, a point brought out in another way in Fig. 8. In constructing this figure advantage has been taken of the fact that during normal growth, over the period studied, the rates of increase of body-weight, liver weight, muscle weight, and liver and muscle DNAP were approximately linear. It is then simple to calculate the percentage daily increase in weight at any time during the linear phase of growth $(d w / d t \times 100 / W)$, where $w=$ weight (of body or organ) and $t=$ time in days. Fig. $8 \mathrm{~A}$ shows the results of this calculation at four points of time up to 30 days from weaning. 
The curves all have the same shape, and the relative rate of increase in muscle weight is throughout slightly greater than that of liver. The protein content of muscle was found to be a little lower than that of liver; therefore, gram for gram, the rate of new formation of protein in the two organs must be of the same order. This finding is remarkable in view of the large difference in their rates of protein turnover. In young rats weighing initially 50-80 g Neuberger et al. (I95I) calculated a half-life of 4-5 days for liver proteins and 24-30 days for the mixed proteins of muscle. The conclusion seems inevitable that during growth the rate of katabolism in muscle must be much lower than in liver. It is this that allows the tissue mass to increase at the same rate in spite of a slower turnover. Such a concept would fit in with the finding of McCance \& Strangeways (I954) that in the young infant the basal metabolic rate involves a smaller breakdown of protein than in the adult.

(3) In Fig. $8 B$ the same method of calculation as in Fig. $8 A$ has been applied to the results during refeeding. Although these are scanty they suggest that whereas in liver the rates of formation of protein and of DNA follow the pattern of growth-fast at first and slower later-in muscle the opposite happens, so that there is a lag in the formation of new muscle. The gain in body-weight shows no lag-or if there is one it could only be detected by measurements made at much shorter time intervals. This discrepancy between the behaviour of the whole body and of muscle fits in with the finding that during the early stages of refeeding body water increases (Table 2).

Such a lag in the formation of new muscle may explain the phenomenon of a stationary phase that sometimes lasts for several weeks in infants recovering from malnutrition (Waterlow, 1955). Two alternative explanations for it have been advanced: that there is an exchange of protein for water and fat, with no net gain in body-weight; or that recovery is slow because synthesizing enzymes are themselves reduced by the protein loss. As yet no decision is possible between these two points of view, both of which may be valid. The problem could best be resolved by producing the stationary phase experimentally. Unfortunately, attempts to do so have so far been unsuccessful. Of the rats on the 'Jamaican' diet, only five out of forty-nine failed to respond almost immediately to refeeding, and this failure was unpredictable, never affecting more than one animal in a litter.

No claim is made that the condition of the rats on the 'Jamaican' diet is the same as the human disease kwashiorkor. Nevertheless, it is reasonable to suppose that the pattern of response to depletion and recovery may follow the same general lines in the two species, when allowance is made for the difference in time-scale.

\section{SUMMARY}

I. Fifty-six weanling rats were fed on a low-protein, high-carbohydrate diet designed to simulate that eaten by poor people in Jamaica. After 4 weeks one group was killed and the remainder were rehabilitated on a stock diet containing $18 \%$ protein.

2. Measurements were made of the protein and deoxyribonucleic-acid content of liver and muscle at the end of the depletion period, at various times during recovery, and also in control animals growing normally. 
3. The 'Jamaican' diet caused a virtually complete arrest of growth. Body-weight, liver weight and muscle weight remained constant at the levels reached on weaning. The ratio of nitrogen to DNA was greatly reduced in both liver and muscle. In muscle this reduction occurred entirely at the expense of cellular protein. The connective tissue of muscle continued to increase in amount throughout the depletion period.

4. On refeeding there was a rapid formation of new protein and DNA in the liver, at about twice the rate that obtains during normal growth. In muscle, on the other hand, there was evidence of a lag period before the synthesis of new tissue reached its maximum rate.

5. The bearing of these results on the assessment and treatment of protein malnutrition in human infants is discussed. They tend to support the suggestion previously put forward, that the ratio of non-collagen nitrogen to DNA in muscle may be a useful index of the degree of protein depletion.

We are indebted to Mrs Valerie King-Hewett, who made the measurements of DNAP per nucleus in the liver. We are also indebted to Dr A. A. Peat, Chief Medical Officer, Jamaica, for permission to publish this paper.

\section{REFERENCES}

Addis, T., Poo, L. J. \& Lew, W. (1936). 7. biol. Chem. 115, I1 .

Balfour, B. M. (1954). In Malnutrition in African Mothers, Infants and Young Children. Report of the Second Inter-African (CCTA) Conference on Nutrition, Gambia, 1952. p. 120. [B. S. Platt, editor.] London: H.M. Stationery Office.

Boehm, J. (1932). Quoted by Pfühl, W. (1932). In Von Moellendorf's Handbuch der mikroskopischen Anatomie des Menschen. Vol. 5, Part 2. Berlin: J. Springer.

Boivin, A., Vendrely, R. \& Vendrely, C. (1948). C.R. Acad. Sci., Paris, 226, 106r.

Burton, K. (1956). Biochem. F. 62, 3 I5.

Campbell, R. M. \& Kosterlitz, H. W. (1949-50). F. Endocrinol. 6, 308.

Campbell, R. M. \& Kosterlitz, H. W. (1952). Science, 115, 84.

Davidson, J. N. \& Smellie, R. M. S. (1952). Biochem. F. 52, 594.

Ely, J. O. \& Ross, M. H. (195I). Science, rr4, 70.

Feng, P. C. \& Kean, E. A. (1955). Brit. F. Nutr. 9, 368.

Fukuda, M. \& Sibatani, A. (1953). Exp. Cell Res. 4, 236.

Harrison, M. F. (1951). Nature, Lond., 168, 248.

Harrison, M. F. (1953). Proc. roy. Soc. B, 141, 203.

Jacob, M., Mandel, L. \& Mandel, P. (1954). Experientia, ro, 2 I 8.

Logan, J. E., Mannell, W. A. \& Rossiter, R. J. (1952). Biochem. F. 5x, 470.

Mandel, P., Jacob, M. \& Mandel, M. (1950). F. Physiol. Path. gén. 42, 662.

McCance, R. A. \& Strangeways, W. M. B. (1954). Brit. F. Nutr. 8, 2 I.

Neuberger, A., Perrone, J. C. \& Slack, H. G. B. (1951). Biochem. F. 49, 199.

Nobécourt, P. (1916). Arch. Méd. Enf. 19, I 13.

Pollister, A. W., Swift, H. \& Alfert, M. (195 I). F. cell. comp. Physiol. 38, suppl. I, Iог.

Rhodes, K. (1952). Brit. F. Nutr. 6, 198.

Schmidt, G. \& Thannhauser, S. J. (1945). F. biol. Chem. r6r, 83.

Schneider, W. C. (1945). F. biol. Chem. 16r, 293.

Stanier, M. W. (1957). Brit. F. Nutr. Ix, 206.

Thomson, R. Y., Heagy, F. C., Hutchison, W. C. \& Davidson, J. N. (1953). Biochem. F. 53, 460.

Waterlow, J. C. (1955). In Protein Malnutrition: Report of a Conference in Famaica, 1953, p. 19. [J. C. Waterlow, editor.] Rome: FAO/WHO/Josiah Macy Jr. Foundation.

Waterlow, J. C. (1956). W. Ind. med. F. 5, 167.

Waterlow, J. C., Bras, G. \& De Pass, E. (1957). F. trop. Pediat. 2, 189.

Waterlow, J. C. \& Weisz, T. (1956). F. clin. Invest. 35, 346.

Widdowson, E. M. \& McCance, R. A. (1957). Brit. F. Nutr. I1, I 98. 